\title{
DIÁLOGO ENTRE PAULO FREIRE E WALTER BENJAMIN: INQUIETUDES SOBRE A ESCOLA E A SOCIEDADE
}

\section{LIDNEI VENTURA}

Universidade do Estado de Santa Catarina

VITOR MALAGGI

Universidade do Estado de Santa Catarina

RESUMO O artigo tem como objetivo colocar em diálogo ideias de Paulo Freire e Walter Benjamin, autores inquietos e críticos de seu tempo, a partir de rememorações de infância ressignificadas pelo olhar dos adultos, em duas obras exemplares: Cartas a Cristina e Infância em Berlim por volta de 1900. Foi usada a metodologia de Benjamin, cujo procedimento consiste em extrair, na forma de mônadas, o objeto literário do contínuo da história, a fim de analisar as relações dos fragmentos monadais com a totalidade histórico-cultural problematizada pelos autores. $\mathrm{O}$ artigo focaliza o olhar dos dois pensadores sobre a educação escolar do seu tempo, dirigindo a ela duras críticas e desvelando o seu caráter conservador e autoritário.

Palavras-chave: Paulo Freire. Walter Benjamin. Dialogismo entre autores. Educação escolar. Mônadas.

\section{ABSTRACT DIALOGUE BETWEEN PAULO FREIRE AND WALTER}

\section{BENJAMIN: CONCERNS ABOUT SCHOOL AND SOCIETY}

The article aims to put into dialogue ideas of Paulo Freire and Walter Benjamin, restless and critical authors of his time, from childhood recollections re-signified by the adults' look at two exemplary works: Letters to Christina and Childhood in Berlin around 1900. It was used the methodology of Benjamin, whose procedure consists in extracting, in the form of monads, the literary object of the continuum of history, in order to analyze the relations of monadic fragments to the historical-cultural totality problematized by the authors. The article focuses on the two thinkers' views on school education of their time, addressing harsh criticism and revealing its conservative and authoritarian character.

Keywords: Paulo Freire. Walter Benjamin. Dialogism among authors. Schooling. Monads. 


\section{RESUMEN DIÁLOGO ENTRE PAULO FREIRE Y WALTER BENJAMIN: INQUIETUDES SOBRE LA ESCUELA Y LA SOCIEDAD}

El artículo tiene como objetivo poner en diálogo ideas de Paulo Freire y Walter Benjamin, autores inquietos y críticos de su tiempo, a partir de rememoraciones de infancia resignificadas por la mirada de los adultos en dos obras ejemplares: Cartas a Cristina e Infancia en Berlín alrededor de 1900. Se utilizó la metodología de Benjamín, cuyo procedimiento consiste en extraer, en forma de mónadas, el objeto literario del continuo de la historia, a fin de analizar las relaciones de los fragmentos monaderos con la totalidad histórico-cultural problematizada por los autores. El artículo se centra en la mirada de los dos pensadores sobre la educación escolar de su tiempo, dirigiendo a ella duras críticas y desvelando su carácter conservador y autoritario.

Palabras clave: Paulo Freire. Walter Benjamin. Dialogismo entre autores. Educación escolar. Mónadas.

\section{Introdução}

Neste artigo, pretendemos colocar em diálogo dois pensadores inquietos e resolutos na crítica que fazem ao seu tempo e, em boa medida, à educação escolar que experimentaram.

Walter Benjamin e Paulo Freire são pensadores inquietos e que inquietam. Não se pode passar pela obra dos dois sem ser envolvido em suas provocações e desassossegos. Isso porque evocam uma visão oblíqua do mundo, colocando em perspectiva as certezas das ciências e a perenidade das instituições.

Embora não possamos confundir a personalidade esperançosa de Freire e a do melancólico Benjamin, cujos traços marcam a produção teórica dos dois autores, parece-nos que a conversa entre eles sugere muitos pontos de contato, tais como a centralidade da linguagem enquanto signo de distinção de humanidade [a linguagem em geral em Benjamin e o dialogismo em Freire], a escovação da história a contrapelo - que dá voz aos oprimidos e esquecidos da historiografia oficial ou a militância crítica contra o status quo da sociedade burguesa e suas marcas distintivas de opressão.

Muitas outras encruzilhadas no caminho poderiam interseccionar as ideias e pensamentos destes dois autores, sobretudo pelo olhar prismático que busca o real em suas múltiplas dimensões. Podemos tão somente aqui apontar limiares possíveis de uma longa prosa, seja à sombra de uma mangueira, num café em Paris, numa viagem ao Chile ou a Capri, ou, então, no exílio, esse não lugar de pertencimento, mas que permite ao mesmo tempo um olhar desviante da terra natal e suas fantasmagorias. Pois é justamente o desvio do olhar que em Benjamin se converte em método ("Methode is Umweg") e que, em Freire, surge como princípio gnosiológico de desvelamento do mundo. Por aproximação, podemos ver que tanto "um-weg" quanto "des-velamento" são palavras compostas por prefixos que guardam uma dupla negação: negação de um olhar engessado e aurático para as coisas do mundo e negação da alienação (FREI$R E, 1987)$ enquanto modo de ver o mundo. 
Embora seja vasto o horizonte de limiares de encontros entre Freire e Benjamin, que pretendemos minimamente enunciar, um deles pode parecer à primeira mão inusitado: a infância. Não a infância idílica e pura dos dois autores, mas, sim, a infância revisitada pela visão poiética do adulto, cujas reminiscências evocam imagens que são postas em relação com o tempo e com os acontecimentos futuros. Para tanto, visitaremos duas obras autobiográficas dos autores: A infância em Berlim por volta de 1900 (2012b), de Benjamin, e Cartas a Cristina, de Freire (2013).

Estas são obras que não podem ser tão facilmente classificadas no gênero autobiográfico, pois ambas são obras de rotura, alegóricas, que no seu desassossego transcendem as autobiografias dos autores na medida em que são colocadas a serviço da expressão de imagens de pensamento que pretendem construir para e com os leitores, sempre abertas [e abrindo] novas significações. A esse respeito, Benjamin fala que essa mesma disposição estava em Proust, pois o autor de Em busca do tempo perdido nunca é somente um excelente autobiógrafo: é alguém que põe as rememorações a serviço da arte para a construção de uma grande imagem de um mundo e de um tempo. Já dizia ele, em $A$ imagem de Proust: "Sabemos que Proust não descreveu em sua obra uma vida como ela de fato foi, e sim uma vida rememorada por quem a viveu" (BENJAMIN, 2012a, p. 38).

E assim fazem Freire e Benjamin, nas suas incursões ao mundo da memória, para extrair de lá, no lusco-fusco das reminiscências, um certo "despertar" de "fantasmagorias", deixando a criança falar pelo adulto a fim de redimir o passado e imobilizá-lo em imagens de desassossego [Unruhen], eivadas de esforços alegóricos, porque sempre imprecisos e sujeitos às benesses de Mnemosine, uma deusa quase sempre temperamental. Assim fala Ben- jamin sobre o impulso alegórico destruidor/ conservador em Baudelaire:

Aquilo que é atingido pela intenção alegórica é arrancado aos contextos orgânicos da vida: é destruído e conservado ao mesmo tempo. A alegoria agarra-se às ruínas. É a imagem do desassossego petrificado. 0 impulso destrutivo de Baudelaire não está nunca interessado na eliminação daquilo que the cai nas mãos. (BENJAMIN, 2006, p. 161)

A reboque da citação acima, apresentamos também o método que guiará nossa exposição, procedimento epistemológico que consiste em arrancar imagens do universo infantil dos contextos orgânicos da vida dos autores a fim de imobilizar, em pequenas mônadas, "iluminações profanas" desassossegadas que olham o passado para ressignificar ações no presente, ou, como a dupla face de Janos, reconfigurar presente e passado.

\section{O exílio e a origem das cartas}

Em uma das suas teses sobre o conceito de história, Benjamin, numa complexa formulação, orienta o historiador [o pensador em geral, o crítico literário ou o filósofo] que a produção de uma dada obra está intrinsecamente vinculada a uma vida vivida por seu autor. O que significa dizer que uma obra em geral apresenta e representa um modo genérico do processo histórico de se viver. Diz ele na Tese XVII: “O resultado desse procedimento é que assim se preserva e transcende (aufheben) na obra o conjunto da obra, no conjunto da obra a época e na época a totalidade do processo histórico (BENJAMIN, 2012a, p. 251, grifos do tradutor).

Ao que parece, então, para se entender determinado pensador, há que se pesquisar não a sua vida particular, mas situá-lo no conjunto da sua obra para transcender nela uma época e o contexto histórico em que sua obra está inserida. É assim que ele encontra o motivo da morte da tradição em Kafka e os motivos mo- 
dernos na obra de Baudelaire e demais autores, sobre os quais se dedicou a estudar.

Evidentemente, só podemos aqui seguir outra pista de Benjamin e indicar alguns limiares das vidas, das obras e da totalidade histórica, contentando-nos em indicar observações acerca de rudimentos de vidas e obras tão amplas e complexas, renunciando a quaisquer perspectivas ilusórias de esgotamento, já que “[...] teremos, aliás, de falar sempre de pormenores, quando a observação mergulha na obra e na forma da arte para avaliar o seu conteúdo substancial (Gehalt)" (BENJAMIN, 2016, p. 33).

Para efeito deste artigo, o texto de Benjamin que escolhemos para dialogar com as Cartas a Cristina de Freire, Infância em Berlim por volta de 1900, será concebido também como uma longa missiva, posto que ambos escrevem cartas. Freire responde à sobrinha Cristina, já do retorno do exílio, depois de ter matutado longamente sobre a resposta a um conjunto de indagações acerca da sua constituição como educador. Benjamin escreve de um passado distante, da sua infância em Berlim, para o filho Stefan [a quem dedica a obra], contando suas peripécias de criança e imortalizando para o filho e à posteridade imagens de uma cidade cujos monumentos, paisagens e modos de vida foram em parte destruídos por guerras e pelas constantes tempestades "vindas do paraíso" do progresso moderno - como ele diz na metáfora do seu Anjo da História, inspirado no Angelus Novus [1920], de Paul Klee.

Os dois autores têm muita coisa em comum, sendo marcante em suas obras a condição de exilados e mesmo de apátridas, pois ambos têm o passaporte retido pelas autoridades. Freire foi acusado de subversão e passou 72 dias preso, em 1964, após o Golpe Civil-Militar que derrubou o governo de João Goulart. Na condição de exilado é que ele iniciou um processo de reflexão e teorização das experiências de alfabetização popular, sobretudo a de
Angicos/RN, que alfabetizou 300 adultos em 45 dias, dando origem a uma proposta de alfabetização revolucionária. Somadas aos 5 anos de trabalhos no Instituto Chileno para a Reforma Agrária (ICIRA), tais experiências foram sistematizadas n'A pedagogia do oprimido [1968], em que explicita a necessidade da construção de uma pedagogia não para o oprimido, mas que parta dele, assim como apresenta a metodologia de trabalho ancorada em temas geradores que brotam do contexto de vida dos educandos.

Assim, é o exílio que lhe permite olhar para trás, para a terra-pátria e reconstruir dialeticamente teoria e prática da educação como conscientização e prática da liberdade/libertação, duas locuções que seriam fundamentais nas obras de Freire. A diáspora freireana continuaria por mais tempo, voltando ao Brasil somente em 1980, depois de 16 anos de peregrinação pelo mundo. Do Chile, lecionou em Harvard em 1969 e, depois, seguiu a Genebra para trabalhar no Conselho Mundial das Igrejas (CMI), prestando consultoria educacional a diversos países, sobretudo africanos. Foi no período suiço que foram gestadas as Cartas a Cristina, em resposta às provocações de uma indagadora sobrinha com quem se correspondia desde os anos de 1970, mas que agora queria mais: “'Gostaria', dizia ela, 'de que você me fosse escrevendo cartas falando algo de sua vida mesma, de sua infância e, aos poucos, dizendo das idas e vindas em que você foi se tornando o educador que está sendo'" (FREIRE, 2013, p. 36).

Assim, graças à menina Cristina, temos hoje essa joia prismática que são as cartas freireanas em resposta às suas curiosidades pueris, no sentido erasmiano.

Se Freire voltou do exílio, Benjamin jamais retornaria: nem vivo, nem morto. Após as perseguições aos judeus com a ascensão no nacional-socialismo em 1932, em março de 1933 
Benjamin imigra voluntariamente para Ibiza, com uma rápida passagem por Paris, para não voltar mais.

Tal como em Freire, as memórias de Infância em Berlim por volta de 1900 têm origem no exílio. Depois de uma estadia em Ibiza, onde poderia viver mais tranquilamente com 70 ou 80 marcos por mês, conforme conta numa carta a Scholem, retornou à França para, num hotel, em Nice, colocar em prática o plano antes cogitado de dar cabo da própria vida. o porquê de não ter executado esse plano ninguém sabe. Só se sabe que Benjamin estava próximo do seu aniversário de 40 anos e que o balanço geral era de que as coisas até ali foram muito mal (SCHOLEM, 1989).

Mas é possivel que o balanço tenha retroagido até à infância, momento em que o adulto Benjamin se encontra com a criança que foi, em flashes de felicidade, proteção, carinho e despreocupação. Talvez o cheiro da maçã no café da manhã antes da escola, da fumaça do fogão à lenha ou o despertar de outros sentidos tenham provocado intensas memórias involuntárias, tal qual a madeleine com chá de Proust, autor no qual se inspira. A Crônica berlinense, texto seminal da Infância em Berlim, foi uma obra encomendada pela revista Literarische Welt, o que possivelmente ativou o balanço geral, dada a penúria financeira geral em que vivia, levando-o a acatar um pensamento próprio que havia formulado um ano antes em O caráter destrutivo: "O caráter destrutivo não vive do sentimento de que a vida vale a pena ser vivida, e sim de que o suicídio não compensa" (BENJAMIN, 1986, p. 189).

De qualquer modo e por razões diversas, Freire e Benjamin colocam as suas cartas a favor da luta política e põem suas autobiografias no jogo de marcação de lugares na luta de classes. Misturando ficção e realidade, como Freire diz ter ouvido de Piaget na TV sobre a memória ou a "força rejuvenescedora" (BENJAMIN, 2012a, p. 47) da memória involuntária, ambos não rememoram tão somente uma infância idílica ou onírica, mas, colocam as memórias à serviço do combate contra a exploração e a alienação generalizada do fantasmagórico e opressor mundo burguês. Essa é uma parte do mundo que se propõem a "despertar", como na metáfora usada por Benjamin no estudo de Paris do século XVIII. De modo que Cartas a Cristina e Infância em Berlim parecem conter um furtivo objetivo de acordar a infância de seus sonhos pueris pela sineta despertadora do olhar adulto sobre seus condicionantes histórico-sociais, a fim de emancipar no passado e no presente os párias da história.

Algumas das imagens despertadas dos sonhos infantis dos autores serão evocadas a partir de um esforço metodológico de transformar tais imagens em mônadas, unidades infinitesimais de pensamento que imobilizam e refletem uma luz momentânea do acontecimento. Segundo o método benjaminiano, a apropriação alegórica significa a cristalização imagética do mundo, arrancando-o do seu contexto vital para permitir outras significações. É como uma fotografia do objeto, que ao mesmo tempo o destrói e conserva na sua essência. Eis aí a imagem benjaminiana como "dialética da imobilidade" (BENJAMIN, 2007, p. 505), cuja função metodológica é de destruição-salvação do fenômeno ou sua petrificação sempre tributária de novas interpretações.

Em Benjamin, as mônadas são imagens da história imobilizadas, sacadas do tempo vazio e homogêneo e do pensamento, para representar uma ideia acerca do universo, unindo a um só termo, no fenômeno, sua ideia e representação [exposição] por meio de uma imagem exemplar, "[...] que retêm a extensão do tempo na intensidade de uma vibração, de um relâmpago, do Kairos" (GAGNEBIN, 2013, p. 80, grifo no original). Segundo sua própria definição: “A ideia é uma mônada - isso significa, em suma, 
que cada ideia contém a imagem do mundo. A tarefa imposta à sua representação é nada mais nada menos que a do esboço dessa imagem abreviada do mundo" (BENJAMIN, 2016, p. 36-37).

Passamos, então, a comentar algumas das imagens da infância cristalizadas nas memórias de seus autores e o que elas revelam ao presente.

\section{Em busca do tempo perdido: 0 tempo reencontrado}

O título do item é proposital e homônimo ao sétimo volume da grande obra de Proust, Em busca do tempo perdido, livro inspirador da Crônica berlinense, que Benjamin transformaria na Infância berlinense (WITTE, 2017).

Nas rememorações da infância, seja em Berlim de 1900 ou do Recife da metade do século XX, Benjamin e Freire recuperam fios de memória que dialogam não somente com suas biografias, mas que se relacionam ao acontecimento total, à vida coletiva. E nisso se distanciam de Proust, que representa a solitude do romancista moderno.

Na medida em que trazem para o presente imagens do passado, os autores lançam não somente uma nova luz sobre ele, iluminando -o profanamente com o olhar do adulto, mas também reivindicam a mudança do presente, pois do passado vem a força messiânica de uma reparação necessária, de algo inacabado que precisa ser redimido. Nesse processo, é reconfigurado o olhar que rememora, na medida em que problematizam o que foi visto pelas crianças, distanciando-se delas e falando por elas. Sobre isso, Freire (2013, p. 22, grifos do autor) diz que "Os 'olhos' com que revejo já não são os olhos com que 'vi'. Ninguém fala do que passou a não ser na e da perspectiva do que passa". No mesmo tom, Benjamin (2012a) diria que as memórias que nos chegam não são ní- tidas, visto que estão sob a dupla dimensão do lembrar e do esquecer. De modo que, nos dois autores, a rememoração tem a função de preservar o passado, não como ele de fato foi, mas como é alargado pela reminiscência, a fim de reinventar o presente. Parece ser isso que Freire (2013, p. 41) quer dizer quando se lembra de que "[...] em tenra idade já pensava que o mundo teria de ser mudado"; muito próximo das preocupações benjaminianas com o "inferno" dos vencidos expressos por "troncos sanguinolentos" (BENJAMIN, 2012b, p. 79) da Coluna da Vitória.

Exercitando uma velha capacidade humana, que Benjamin diz ter entrado em decadência na modernidade, a de perceber semelhanças, escolhemos três mônadas que entendemos como similares em Benjamin e em Freire, embora os contextos históricos e culturais de ambos fossem muito diferentes. De qualquer forma, o esforço é buscar nos autores "imagens que lampejam" e façam brilhar no "pequeno momento individual o cristal do acontecimento total", interrompendo o contínuo da história dos autores para imobilizar uma imagem exemplar. Mas não como puro deleite teórico ou eivado de curiosidade biográfica, mas como propedêutica de como o passado pode servir de luz ao presente. Chamaremos essas mônadas de: "1. 0 anjo de natal, mendigos e prostitutas e o piano e a gravata de meu pai"; "2. 'Seu' Armada e Sr. Knoche"; 3. Maçãs, mamões, memórias involuntárias e razões de radicalidade.

A ideia consiste em aplicar o método benjaminiano de monadalisar os fragmentos narrativos dos autores, procurando captar imagens que retenham micromundos de significados histórico-culturais.

"O anjo de natal, mendigos e prostitutas e o piano e a gravata de meu pai" é uma mônada construída em dois tempos: ao passo que evoca excertos de duas narrativas da Infância em Berlim: "Um conto de natal" e "Mendigos e 
prostitutas", entrecruza esses fragmentos com dois objetos simbólicos presentes na segunda Carta a Cristina: "A gravata de meu pai e o piano alemão da tia Lourdes", que expressam e denunciam condições de classe.

Já a mônada "'Seu' Armada e Sr. Knoche" põe em relação retalhos de histórias que propõem uma crítica direta da escola tradicional, autoritária e instrumental, personificada no "Seu" Armada, duro mestre-escola de Freire; símile do Sr. Knoche, que encarna o modelo de escola enfadonho e destituído de significado, cujos aborrecimentos são rememorados por Benjamin.

Por fim, em "Maçãs, mamões, memórias involuntárias e razões de radicalidade", buscamos articular a crítica efetivada por Benjamin e Freire nas mônadas anteriores, sobretudo pelo viés de uma reflexão profunda sobre a escola e as condições de classe, que brotam de lampejos mnemônicos renascidos pela via do "recobrar com/pelos sentidos".

\section{0 anjo de natal, mendigos e prostitutas e o piano e a gravata de meu pai}

Como disse Jeane Marie Gagnebin (2013, p. 73), a Infância em Berlim por volta de 1900 é uma "pequena obra prima". E essa condição exemplar é reafirmada em cada estilhaço de imagens de um passado que dá fôlego ao Anjo da História, que the permite respirar para "[...] acordar os mortos e juntar os fragmentos" (BENJAMIN, 2012a, p. 245) de um mundo em ruínas. Esse anjo visita o Benjamin criança numa noite de natal, travestido de anjo natalino, para "salvar" os esquecidos da história; assim como o ajuda na construção de um front de batalha contra o esquecimento e a invisibilidade dos "outros": pobres, mendigos e prostitutas, liberando-se da prisão no novo Oeste, em cujo feudo se via encarcerado pelo clã familiar. Analogamente, Freire não somente adere, mas reitera a função despertadora da re- memoração, desenterrando dos escombros do passado o mundo dos que não comiam, “[...] o mundo dos meninos e das meninas dos córregos, dos mocambos, dos morros" (FREIRE, 2013, p. 53). De modo que nossa fragmentária mônada freire-benjaminiana procura "imobilizar" algum brilho de instantes tão intensos, como os descritos a seguir:

Tudo começava com os pinheiros. Ao sairmos para a escola, certa manhã, surgiam grudados nas esquinas os lacres verdes que pareciam fixar a cidade em centenas de pontos, como se fosse um enorme presente de Natal. Não obstante, um belo dia a cidade rompia esse invólucro, e de suas entranhas brotavam brinquedos, nozes, palha e adorno para a árvore: o mercado do $\mathrm{Na}$ tal. Mas com ele surgia também outra coisa: a pobreza. [...] Porém, como aquela constelação por vezes agraciava uma das janelas abandonadas, enquanto muitas permaneciam escuras, e outras, ainda mais tristonhas, se atrofiavam à luz de gás da noite emergente, parecia-me que essas janelas natalinas continham em si a solidão, a velhice e a indigência - tudo aquilo que os pobres calam. (BENJAMIN, 2012b, p. 122-123)

Em minha infância fui prisioneiro do antigo e novo Oeste [...] Nesse bairro de proprietários, permaneci encerrado sem saber da existência de outros. Os pobres - para as crianças ricas de minha idade - só existiam como mendigos. E foi um grande avanço do conhecimento quando comecei a entender a origem da pobreza na ignomínia do trabalho mal remunerado [...] Mas naquela época eu não podia conceber outra forma de revolta que não fosse à sabotagem, e esta obviamente por experiência própria. [...] De todo modo, não havia dúvida que o sentimento - infelizmente, ilusório - de abjurar minha mãe, sua classe a minha, era o responsável pela atração sem igual de me dirigir a uma prostituta em plena rua. (BENJAMIN, 2012b, p. 127-128)

Nascidos, assim, numa família de classe média que sofrera o impacto da crise econômica de 1929, éramos 'meninos conectivos' [...]. (FREIRE, 2013, p. 52)

No esforço constante de rever-me recordo como, apesar da fome que nos solidarizava 
com os meninos e meninas dos córregos, não obstante o companheirismo que nos unia, nos brinquedos, como na busca de sobrevivência, éramos para eles, porém, muitas vezes, meninos de outro mundo, acidentalmente o seu. Estas fronteiras de classe que o homem de hoje percebe claramente, ao voltar-se sobre o seu passado, e que o menino de ontem não entendia, eram expressadas, de forma ainda mais clara, por alguns dos pais de nossos companheiros de então. [...]. (FREIRE, 2013, p. 52)

Em nossa casa havia um piano alemão em que Lourdes, uma de nossas tias, tocava Chopin, Beethoven, Mozart. Bastava o piano para nos distinguir, como classe, de Dourado, de Reginaldo, de Baixa, de Toinho Morango, de Gerson Macaco, alguns amigos daquela época. 0 piano, em nossa casa, era como a gravata no pescoço de meu pai. [...]. (FREIRE, 2013, p. 53)

O piano de Lourdes e a gravata de meu pai faziam o mesmo jogo que os jacarandás e as louças de alto requinte fazem ainda hoje no Nordeste brasileiro entre os aristocratas decadentes. (FREIRE, 2013, p. 54)

É interessante observar que, nas Cartas a Cristina, Freire inicia seu périplo rememorativo enfatizando justamente as questões de classe que perpassaram a sua infância e que, pelos olhares desviantes do adulto, são distintivas para marcar a sua "tomada de consciência" acerca de como tal condição constitui a radicalidade de sua proposta político-pedagógica. As táticas simbólicas utilizadas por sua família, enquanto momentos estratégicos de sobrevivência no interior de uma sociedade classista, pode-se dizer que reforçavam na criança justamente a construção da ideia de que "[...] o mundo teria de ser mudado" (FREIRE, 2013, p. 42). Tais questões de classe explicam, também, o fato de que em Freire tal tomada de consciência, inicialmente, não vem adensada por uma repulsa explícita a tais táticas simbólicas. Isto porque, de fato, eram necessárias para que a sobrevivência da família fosse possivel em níveis minimamente condizentes com sua pretensa posição de classe. Como bem ressalta Freire, "[...] fronteiras de classe que o homem de hoje percebe claramente, ao voltar-se sobre o seu passado, e que o menino de ontem não entendia [...]" (FREIRE, 2013, p. 51-52).

Em Benjamin, contudo, encontramos na "descoberta" da miséria no mundo um sentimento inicial de "repulsa" aos valores e comportamentos de classe expressos no seu núcleo familiar. o que, no limiar, o conduz a uma aproximação com aqueles que, na sociedade de classes, são vistos como "párias" - por exemplo, as prostitutas. A poética benjaminiana, ao comparar imageticamente o pretenso "belo" da cidade enfeitada para o Natal, contrastada com as janelas onde residem os "esquecidos" pela sociedade, o conduzem ao movimento de, por um lado, descobrir a "feiura" no mundo e, por outro, rebelar-se contra ela de forma ainda romântica, buscando conectarse com este outro lado da sociedade ao passo em que, também, nega aquilo que constitui o seu núcleo familiar burguês.

Obviamente, tal constatação não mitiga o fato de que, no pequeno Freire, táticas menos explícitas acabam por conduzi-lo a uma aproximação existencial e de classe com seus pares populares, por assim dizer. Constitutivo desta visão de "menino conectivo", que percebemos também em Benjamin, rebela-se por assim dizer contra o status quo pelo simples fato de transitar por entre dois mundos, não os cindindo tal como a gravata de seu pai fazia, em nível ideológico. Por mais que tal atitude não apague as distinções de classe e suas artimanhas para demarcá-las, Freire, já em sua infância, andarilhava pelas fronteiras, pelas bordas móveis que constituem o tecido social, ao ter, em seus mais diletos amigos, filhos da classe trabalhadora expropriada pela sociedade - os meninos dos mocambos e córregos. Através deles, podemos assim entender, o Freire adulto revisitando sua infância ao mesmo tempo que 
"redescobre" e "reafirma" uma dimensão essencial da sua práxis político-pedagógica: a de que, em um mundo social cindido em classes antagônicas, colocar-se ao lado dos oprimidos significa com eles construir uma pedagogia de sua libertação. Ou seja, não uma visão idealista de liberdade individual, de cunho meramente psicológico, mas liberdade enquanto processo contínuo de libertação - luta para transformar os impeditivos concretos ao "ser mais" dos homens e mulheres, dos quais a questão de classe é, sem dúvida, um dos principais elementos.

Assim, vemos que a dimensão de classe na realidade social é percebida inicialmente por Freire e Benjamin por intermédio de sua dimensão simbólica, portanto ideológica. Confrontando-as com aspectos de sua condição concreta, conseguem realizar um processo inicial de ad-miração que os guia ao reconhecimento das origens deste estado de coisas. Algo que, no Freire e no Benjamin adultos, serão marcas distintivas da práxis emancipatória que advogam. No natal em Berlim, Benjamin parece constatar duas cidades distintas, cindidas pelo lugar que os sujeitos ocupam na (re)produção do social. A gravata e o piano em Freire são, em Benjamin, a cidade enfeitada para o Natal. De ambos, contudo, emergem seu contrário dialético: em Freire, a crua realidade que os obriga a se distinguirem simbolicamente no tocante à questão de classe como pura estratégia de sobrevivência; em Benjamin, irrompe da suposta harmonia e beleza citadina do Natal imagens de janelas escuras, que abrigam tristezas tantas - a solidão, a indigência e "tudo aquilo que os pobres calam".

Em suma, as reminiscências dos adultos Benjamin e Freire sobre a infância acabam por apontar para algo de essencial na totalidade, a partir do fragmentário-particular: que uma realidade permeada de "malvadeza" existe a partir da condição de classe dos sujeitos nela presentes, apesar de que, por artimanhas vá- rias - às vezes, de pura sobrevivência, como em Freire -, muitas vezes tenta-se escamoteá-la, encobri-la. Freire e Benjamin demonstram, portanto, o papel dialético que o simbólico possui neste processo de reprodução do metabolismo social - ou seja, a construção e a manutenção dos valores, formas de ser e ideias das classes sociais.

\section{'Seu' Armada e Sr. Knoche}

A presente mônada rememora nos autores os tempos de escola, fazendo ressurgir do cenário educacional dois personagens exemplares de quanto o espaço escolar pode ser opressor, sobretudo quando flagram as crianças que foram em situações humilhantes ou sob aborrecimentos constantes. Longe de falar ao passado, esses lampejos memoriais iluminam não só o presente, mas o futuro, reivindicando a realização de uma educação emancipatória, prometida desde o Iluminismo. Esta mônada que compusemos tem por base algumas iluminuras da sexta Carta a Cristina e duas narrativas da constelação benjaminiana: Duas imagens enigmáticas e $A$ biblioteca do colégio.

'Seu' Armada era um homem alto, um homem do povo, de poucas letras, gordo como Adelino, bem mais moço que ele e sem, certamente, jamais os momentos de ternura de que Adelino pontilhava seus instantes ásperos. (FREIRE, 2013, p. 101)

Só em saber das estórias em torno do professor eu reagia duramente contra ele. Enquanto escutava, por exemplo, as estórias que nosso amigo nos contava na beira do rio, eu sonhava com vê-lo proibido de ter escola e posto de joelhos sobre grãos de milho, tal qual ele fazia com os meninos. (FREIRE, p. 101)

[...] 'Seu' Armada, contado, não era uma exceção nem uma extravagância cultural. Havia outros tantos Armadas, cuja disciplina férrea imposta aos alunos era inclusive requerida pelos pais e pelos mais convencidos de que o tratamento duro é que faria de seus filhos gente séria. (FREIRE, 2013, p. 102) 
[...] A tradição autoritária brasileira, a memória escravocrata, a experiência de exacerbação do poder que corta, entre nós, as classes sociais, tudo isso explicada 'seu' Armada. 'Seu' Armada não poderia, na verdade, existir só, como se fosse incômoda exceção. (FREIRE, 2013, p. 102)

'Seu' Armada não contestava; pelo contrário, confirmava nossas tradições autoritárias. (FREIRE, 2013, p. 02)

O senhor Knoche tomou o lugar da senhorita Pufahl. A essa altura, eu já frequentava a escola. Tudo o que sucedia na sala de aula, de modo geral, me repugnava. Contudo, não é por uma de suas punições que o senhor Knoche me vem à lembrança, mas pelo ofício de vidente, que prevê o futuro, e que não the caía mal. (BENJAMIN, 2012b, p. 93)

[...] E do nome que outrora havíamos memorizado não sabia mais que o que o verso da Canção dos Cavaleiros, agora que eu a compreendia, continha o significado que o senhor Knoche nos havia prognosticado na aula de canto. A tumba vazia e o coração disposto - dois enigmas de cuja solução a vida há de continuar a me ser devedora. (BENJAMIN, 2012b, p. 93)

Era no intervalo da aula que a coisa era feita: juntavam-se os livros que, em seguida, eram de novo repartidos entre os pretendentes. Nem sempre conseguia ser bastante ágil. Muitas vezes vi livros por mim almejados caírem em mãos de quem não saberia apreciá-los. Quanta diferença entre o seu mundo e o dos compêndios escolares [...] Pior eram as casamatas dos poemas pátrios, onde cada verso equivaleria a uma cela [...] Porém, fossem esses livros agradáveis ou medonhos, aborrecidos ou excitantes - nada podia diminuir-lhes o encanto. Pois este não dependia do conteúdo, mas sim do fato de me garantirem um quarto de hora que tornasse mais tolerável toda a miséria da monotonia das aulas. (BENJAMIN, 2012b, p. 115-117)

Ao que parece, a mônada acima apresenta-se em pares historicamente isonômicos da escola: miséria-monotonia; repugnância-castigo. Ao mesmo tempo, sintetiza possibilidades diversas de reflexões pedagógicas em torno da escola, sua relação com a cultura e os contextos socioeconômicos em que se situa. $E$, neste sentido, em como tais relações espelham-se nas atitudes daqueles sujeitos que compõem tais espaços institucionais de ensino-aprendizagem. Sem pretendermos explorar, contudo, toda a miriade relacional acima anunciada, intencionamos compreender como a escola, enquanto microcosmo social, muitas vezes introjeta em suas práticas a "cultura do silêncio", denunciada por Freire e, também, por Benjamin. Enquanto marca distintiva da sociedade capitalista, patriarcal e escravocrata brasileira, historicamente construída sob o jugo colonizador português (posterior e, atualmente, diríamos, do Império sintetizado no mercado financeiro global), tal cultura desenvolve-se mirando possibilidades de anulação da autonomia, do posicionar-se criticamente frente à realidade. Marca que Benjamin encontrará, também, no tradicional sistema educacional de inspiração prussiana.

A "cultura do silêncio" presente no Nordeste brasileiro de Freire significava a transformação dos seres humanos, compreendidos como "seres ontologicamente e historicamente vocacionados a ser mais", em meros "objetos" passivos e manipuláveis pelas classes dominantes desta sociedade. Ou seja, seres sem processo de busca contínua, sem ponto de decisão em si mesmos, sem radicalidade e, assim, sem criticidade. Para Freire (2010b), a cultura do silêncio, enraizada na formação histórica da sociedade brasileira, conforma-se na sua dimensão comunicacional por meio de ações em que um sujeito transmite informações, ordens, comunicados a outros sujeitos. Logo, os receptores das informações não operam nenhuma transformação sobre os significados contidos nas palavras que compõem a mensagem, posto que são passivos neste processo. Assemelham-se, de fato, mais a um "objeto" receptor do que propriamente a um su- 
jeito comunicante (FREIRE, 1977). Desta forma, Freire (2010a, p. 74) expõe que, na "[...] cultura do silêncio, existir é apenas viver"; ou seja, o sujeito é transformado em uma mera "presença" no mundo. Não existe em todo o potencial humano que the é intrínseco, que é o de ser sujeito da ação e da reflexão com os demais seres humanos, em uma relação de igualdade e reciprocidade em que se busca compreender e transformar o mundo, ou seja, humanizá-lo.

Tal dimensão cultural, arraigada fortemente nas estruturas sociais autoritárias, parecem ser percebidas por Freire e Benjamin como influências decisivas nos processos educativos escolares. Para Benjamin, o exercício docente do senhor Knoche aproxima-se mais ao do vidente do que de um educador que, por intermédio de sua intervenção pedagógica decisiva, deveria convidar os educandos com suas curiosidades para a alegria e o desafio de desvelamento da realidade. Benjamin, em um tom irônico, critica a educação ausente de conexão com a vida "vivida" pelas crianças, aquela que sempre parece se remeter ao: "no futuro vocês saberão para que isso serve". Enxerga, assim tal como Freire, um traço do autoritarismo sintetizado neste caso nas figuras docentes - desprendendo-se da totalidade social mais ampla, que busca (de)formar os sujeitos para se tornarem apáticos frente à realidade e aos outros. É por isso que, para Benjamin, a escola em seus momentos mais "escolares" the parece "repugnante", "monótona". Entretanto, é instigante e inusitado pensar que a imagem benjaminiana reivindicaria muito mais a visão profética do professor do que ele imaginaria. Revisitando o passado, o adulto Benjamin jamais saberia que a vida lhe seria devedora sobretudo de uma "tumba vazia" na distante e fronteiriça Portbou.

É importante perceber, entretanto, que nem Benjamin, nem Freire, associam a tradição verbalista e memorizadora da escola com uma negação do papel da cultura na formação dos sujeitos. Em última instância, ao papel que o currículo escolar pode e deve ter nos processos educativos. Se Freire implicitamente postula uma crítica à noção de alfabetização enquanto memorização do código escrito, ao denunciar o "ba be bi bo bu" da didática "armadista", nem por isso desconsidera o papel que a escola e seus(uas) educadores(as) possam ter na apropriação crítica da língua escrita. Basta lembrar como, nas demais Cartas a Cristina, Freire recorda-se de professoras(es) que the colocaram a língua portuguesa não enquanto objeto "dado" de conhecimento, mas objeto a ser curiosamente apropriado pelo educando, com a intervenção pedagógica do educador. Benjamin também não parece ver nos livros uma expressão unívoca de uma cultura escolar livresca; parece, isto sim, perceber que, quando a cultura sintetizada num livro, se é posta como desafio prazeroso de aprendizagem, estamos superando justamente a concepção epistemológica equivocada da "educação bancária", denunciada por Freire enquanto "concepção digestiva do saber" (FREIRE, 2010b).

Neste sentido, poderíamos também acrescentar que a crítica ao autoritarismo presente na escola verbalista, enfadonha, desconectada da realidade dos educandos, feita tanto por Benjamin quanto por Freire, não postula validade pedagógica a processos educativos sem qualquer diretividade. Como bem ressalta Freire, se trata de, ao negar o autoritarismo e a licenciosidade, afirmar “[...] uma prática democrática em que nem a autoridade se exacerbe, afogando a liberdade, nem esta, hipertrofiada, anule a autoridade, mas em que, limitando a liberdade, a autoridade igualmente se limite" (FREIRE, 2013, p. 102). Tanto pela experiência vivencial de Freire quanto de Benjamin, percebemos que a presença de "Armadas" e "Knoches" nos remete a (re)pensar a escola como 
um verdadeiro espaço de conhecimento, que não se dá alijado da curiosidade, da busca incessante, do prazer de aprender, do perguntar que move e nos direciona "de corpo todo" ao conhecimento. Processos que, em última medida, são contra-hegemônicos à relação desta instituição com o que dela se espera pela sociedade opressora - o mero "treinamento" de pessoas para, no futuro, desempenharem seu papel na reprodução da engrenagem social.

\section{Maçãs, mamões, memórias involuntárias e razões de radicalidade}

Da teoria da memória proustiana, Benjamin enfatizou o papel das memórias involuntárias, aquelas que nos chegam de assalto, que trazem consigo a integralidade do ser, pois suas rememorações vêm a lume pela integralidade dos sentidos, ampliando e mesmo ressignificando a concepção racionalista da memória que fica presa ao intelecto. Para Benjamin, ao contrário, pelas armadilhas da memória, quanto mais tentamos nos lembrar, mais nos esquecemos. E antes de lembrar o passado, o processo de rememoração trata de presentificá-lo, pois “[...] a maioria das recordações que buscamos aparecem à nossa frente sob a forma de imagens visuais" (BENJAMIN, 2012a, p. 50).

A mônada que apresentamos adiante tem a intenção de reiterar o papel da diversidade dos sentidos, cujas impressões funcionam como ativadoras de recordações: texturas, aromas, odores... Aliás, é o odor da madeleine mergulhada no chá que ativa em Proust as reminiscências do Caminho de Swann, o primeiro dos sete livros que compõem sua grande obra: $\mathrm{Em}$ busca do tempo perdido. o cheiro da maçã na mônada "Manhã de inverno", da Infância em Berlim, será conjugado a fragmentos de episódios de Jaboatão, contados por Freire na 7ạ Carta a Cristina, hibridizando as narrativas para originar uma nova imagem de pensamento, que chamamos de Maçãs, mamões, memórias involuntárias e razões de radicalidade. Nela, são imobilizadas imagens nas quais os adultos recordam as crianças que foram para inventariar sua história e problematizar o presente.

Quando a estufa já estava abastecida, ela punha uma maçã para assar na estufa. Daí a pouco, a grade da portinhola da lareira se desenhava no chão como um rubro bruxulear. E era como se, para o meu cansaço, aquela imagem the tivesse dado o suficiente para o dia. Isso sempre se dava àquela hora; apenas a voz da babá perturbava a prática por meio da qual a manhã de inverno costuma me unir aos objetos em meu quarto. A persiana ainda não fora erguida quando já pela primeira vez eu afastava a tranca da portinhola da estufa a fim de seguir o rastro da maça no duto. Por vezes, ainda mal alterara seu aroma. [...] Lá estava a fruta escurecida e quente [...] Sentia que o fugaz conhecimento que me aportava em seu aroma podia me escapar com toda a facilidade ao passar por minha língua. Conhecimento que, às vezes, me instilava tanta coragem que, no caminho da escola, me servia ainda de consolo. Quando lá chegava, porém, no contato com meu banco, toda aquela fadiga, que parecia ter se dissipado, voltava decuplicada. E com ela o desejo de poder dormir até dizer basta. Devo tê-lo experimentado milhares de vezes, e, mais tarde, de fato, ele se cumpriu. Custou-me, porém, muito tempo para nisto reconhecer que fora sempre vã a esperança que eu nutria de ter colocação e sustento garantidos. (BENJAMIN, 2012b, p. 85)

Jaboatão ia se dando a nós como um novo mundo, bem mais vasto do que o que nós experimentávamos até então, o do quintal de nossa casa do Recife. Um mundo cheio do verde da cana-de-açúcar, do cheiro de seu caldo, do cheiro do melado dos engenhos. [...] Mas um mundo também em que a exploração e a miséria dos camponeses iam se revelando a nós em seu dramático realismo. É aí que se encontram as mais remotas razões de minha radicalidade. (FREIRE, 2013, p. 115)

[...] em pouco tempo éramos os 'meninos conectivos' a que antes me referi, com amigos entre os que comiam e entre os que quase nada comiam. 
Com um deles, Dino, menino de classe média, como eu, já várias vezes referido nestas cartas, costumava conversar, na beira do rio, à sombra dos ingazeiros, enquanto pescávamos, sobre as nossas dificuldades. Foi ele que me ensinou, um dia, um prato gostoso, mas sobretudo acessivel as nossas possibilidades, e que se tornou uma constante em nossa dieta: fritada de mamão. 'É preciso', dizia ele com segurança, 'que o mamão esteja em vez. Nem maduro nem verde, em vez', repetia para que eu não errasse.

Os mamoeiros dos vizinhos estavam a nosso alcance e os ovos de galinhas andarilhas, pondo aqui e ali, não faltavam. (FREIRE, 2013, p. 115-116)

Em um dos seus mais belos textos, "O narrador", Benjamin diz que narrar é partilhar experiências; neste sentido, Freire e Benjamin são exímios narradores, pois as memórias acima compartilhadas conosco mais do que contar lindas histórias, retratam como as "retretas" da infância participam do jogo de forja da subjetividade adulta. De modo que as rememorações da maçã trazem consigo não somente o cheiro e o sabor da fruta cozida, mas sim todo um conjunto de significados, assim como os mamões fritos. A maçã surge como um alento à fadiga proporcionada pelo banco escolar, que reitera em voltar. Esse passo está por demais ligado às narrativas antecedentes do quanto a escola é um lugar enfadonho, a ponto de decuplicar a fadiga experimentada pela criança berlinense que tinha que acordar cedo numa manhã de inverno. Certamente isso nos lembra também as manhãs dificeis que crianças de todos os lugares experimentaram para se dirigir à escola; mas nem todas guardam, nem deveriam guardar, essa sensação de fadiga decuplicada.

Ao que parece, esse sentimento de criança cansada acaba se revelando também no adulto fadigado por não encontrar neste mundo um lugar definido e sustento próprio. Como se sabe, a vida econômica de Benjamin foi de apertos constantes, vivendo no limite e, muitas vezes, em condições precárias; mas se pode supor que cada maçã se converteu frequentemente em um brilhante texto que "[...] instilava tanta coragem que, no caminho da escola [da vida], me servia ainda de consolo" (BENJAMIN, 2012b, p. 85). Pelo lado freireano, nos parece que os mamões compartilham também experiências de resistência e consolação, acabando por revelar o mundo da fadiga dos explorados e cansados camponeses. Enquanto mediador da experiência dos que comiam ou quase nada comiam, os mamões informam acerca de "caças não autorizadas", como dizia Certeau (2014, p. 38), enquanto tática de subsistir em terra alheia. Diante de uma imagem potente como essa, Freire não regateia em atualizá-la como razão de radicalidade. Percebe-se também, ao longo da obra benjaminiana, que muitas das razões da acentuada radicalidade do seu pensamento estão presentes nas memórias da Infância em Berlim, que são despertadas pelos cheiros e imagens de pensamento que enxameiam o pensamento do adulto e acabam por salvar o passado do esquecimento para ressignificar o presente.

\section{Não querendo acabar...}

Escrever é correr riscos. Mas repetindo um adágio atribuído a Sêneca, a coragem é jamais fora de propósito. Parece corajoso e ao mesmo tempo arriscado tentar colocar em diálogo pensadores tão diferentes, como tentamos ao longo desta discussão. Todavia, mais do que qualquer outro impulso, procuramos reivindicar uma faculdade humana em decadência, como disse Benjamin, a faculdade de perceber semelhanças, cuja percepção está ligada a um relampejar, a uma iluminação súbita, que pudesse de alguma forma entrelaçar similitudes desses poderosos autores.

Em função disso, não queremos acabar...

Esperamos ter apontado alguns limiares de entrecruzamentos teóricos de Walter Benja- 
min e Paulo Freire. Embora tais aproximações possam escandalizar "puristas" de um ou outro autor, a iniciativa teve por objetivo a busca de semelhanças entre preocupações que vinham desde a infância e se tornaram centrais nas suas elaborações teóricas de adulto. Como a obra de Benjamin chegou tardiamente ao Brasil, justamente quando Freire já estava no exílio, e contingências históricas não tenham permitido o diálogo direto dos dois autores, ousamos neste breve trabalho apontar inquietudes comuns a esses pensadores.

Cabe reiterar, finalmente, o movimento desviante do método que orientou o artigo: o processo de produção de mônadas a partir das narrativas de infância presentes em $A$ infância em Berlim por volta de 1900 e em Cartas a Cristina, em função do caráter fragmentário tanto de recorte quanto da análise de narrativas de ambos os autores. Diante disso, o esforço metodológico foi o de arrancar algumas narrativas infantis do contínuo das histórias vividas pelos autores, transformá-las em mônadas e analisar como essas imagens micrológicas de pensamento reivindicam no seu interior espectros de um tempo e de uma totalidade histórica que supera a vivência individual.

Longe de quaisquer pretensões de acabamento ou conclusões estanques, coube ao artigo apenas sinalizar as possiveis relações de aproximação entre dois dos maiores pensadores do século XX.

\section{Referências}

BENJAMIN, W. Documentos de cultura, documentos de barbárie: escritos escolhidos. São Paulo: Cultrix; Edusp, 1986.

Parque central; a modernidade. Tradução de João Barrento. Lisboa: Assírio \& Alvim, 2006.
Passagens. Org. ed. alemã Rolf Tiedemann; Org. ed. brasileira Willi Bolle. Belo Horizonte: Editora da UFMG, 2007.

Obras Escolhidas I, Magia e técnica, arte e política: ensaios sobre literatura e história da cultura. Tradução de Sérgio P. Rouanet. São Paulo: Brasiliense, 2012a.

Obras escolhidas II, Rua de mão única. Tradução de Rubens J. T. Filho; José Carlos M. Barbosa. São Paulo: Brasiliense, 2012b.

Origem do drama trágico alemão. Tradução de João Barrento. 2. ed. Belo Horizonte: Autêntica, 2016.

CERTEAU, M. de. A invenção do cotidiano: artes de fazer. 21. ed. Petrópolis, RJ: Vozes, 2014.

FREIRE, Paulo. Ação cultural para a liberdade e outros escritos. 13. ed. Rio de Janeiro: Paz e Terra, 2010 a.

Educação como prática da liberdade. 33. ed. Rio de Janeiro: Paz e Terra, 2010b.

Extensão ou comunicação? São Paulo: Paz e Terra, 1977.

Pedagogia do oprimido. Rio de Janeiro:

Paz e Terra, 1987.

Cartas a Cristina: reflexões sobre minha vida e minha práxis. Rio de Janeiro: Paz e Terra, 2013.

GAGNEBIN, J-M. História e narração em Walter Benjamin. São Paulo: Perspectiva, 2013.

KOTHE, F. R. A alegoria. São Paulo: Ática, 1986.

SCHOLEM, G. Walter Benjamin: a história de uma grande amizade. São Paulo: Perspectiva, 1989.

WITTE, B. Walter Benjamin: uma biografia. Belo Horizonte: Autêntica, 2017.

Recebido em: 04.10.2018 Aprovado em: 20.03.2019 
Lidnei Ventura é Mestre em Educação e Cultura pela UDESC e Doutor em Educação pela UFSC. Professor adjunto do Centro de Educação a Distância da UDESC, atuando na disciplina de Estágio Curricular Supervisionado de Ensino e outras disciplinas da base curricular da Pedagogia.e-mail: llrventura@gmail.com

Departamento de Pedagogia a Distância, CEAD/UDESC.

Rua Antônio Heill, 388, apt. 201. Canasvieiras. Florianópolis, SC. Cep: 88054-160. Fone: (48) 991174017

Vitor Malaggi é Mestre em Educação pelo Programa de Pós-Graduação em Educação (PPGEDU/UPF). Professor assistente do Centro de Educação a Distância da Universidade do Estado de Santa Catarina (CEAD/UDESC). e-mail: malaggi@ gmail.com

Departamento de Pedagogia a Distância, CEAD/UDESC.

Rua Salvatina Feliciana dos Santos, 155, apto 308A. Itacorubi. Florianópolis, SC. Cep: 88034-600. Fone: (48) 999546095 